\title{
Genetic relationship between days open and days dry with milk yield in a herd of Holstein Friesian cattle
}

\begin{abstract}
Summary
A total of 2897 lactation records of Holstein Friesian cattle from the fields of Dena Farm in Egypt from 1987 to 1993 were used to study relationships of days open and days dry with milk production. The effect of month and year of calving, sire and cow within sires were also investigated.

Month of calving, year of calving, sire and cow within sires significantly influenced milk production.

Including DO and DP as a polynomial of second degree of production were significant. The partial linear and quadratic regression coefficients of 305 day milk yield on DO and DP were significant, being $7.59 \pm 0.40 \mathrm{~kg} / \mathrm{d}$ and $-0.37 \pm 0.00 \mathrm{~kg} / \mathrm{d}^{2}$, respectively for DO and $-9.37 \pm 0.54 \mathrm{~kg} / \mathrm{d}$ and $0.02 \pm 0.00 \mathrm{~kg} / \mathrm{d}^{2}$, respectively for DP. Therefore, reduction of DO and DP are a desirable goal of dairymen.

Heritability $\left(h^{2}\right)$ estimates for 305 day milk yield, DO, DP were $0.13 \pm 0.05,0.00$ and 0.00 , respectively. Adjustment of lactation milk yield for DO will not involve genetic influence on milk yield.
\end{abstract}

Key Words: days open, days dry, lactation, genetic relationship, heritability

\section{Resumen}

Titulo del Articulo: Relación Genética Entre Días Abres y Días Secas Con Rendimiento de la Leche en un Rebafio de Holstein Frison Vacuno

Un total de 2897 registradas de lactacion de Holstein Frison vacuno de Dena granja en Egipto de 1987 a 1993 se usaron a estudiar las relaciones de dias abres y días secas con producción de leche. El efecto del mes y año de parto, padre y vaca dentro de padres también se investigó.

Mes de parto, año de parto, padre y vaca dentro de padres influyó !a producción de leche significativamente.

Icludiando días abres y periodos secos como una polinomial grado segundo de la producción era significativos. Coeficientes de regresión lineal parcial y cuadrático de 305 día leche rendimiento días sobre dias abres y períodos secos eran significativos, estando $7.59 \pm 0.40 \mathrm{~kg} / \mathrm{dia}$ y $-0.37 \pm 0.00 \mathrm{~kg} / \mathrm{dia}^{2}$ respectivamente por dias abres, $-9.37 \pm 0.54 \mathrm{~kg} /$ dia y $0.02 \pm 0.00 \mathrm{~kg} / \mathrm{dia}^{2}$ respectivamente por períodos secos. Por eso, reducción de dias abres y períodos secos son una meta deseable de ganaderos lecheros.

Heritabilidad estima para 305 día leche rendimiento, días abres, periodos secos eran $0.13 \pm 0.05,0.00$ y 0.00 , respectivamente. Ajuste de rendimiento de leche de lactacion para días abres no envolverán influencia genética en rendimiento de leche.

Palabras claves: Dias abres, dias secas, lactacion, relación genetica, heritabilidad

\section{Zusammenfassung}

Titel der Arbeit: Beziehungen zwischen Zwischentragezeit und Trockenstehzeit zum Milchertrag einer Holstein-Friesian-Herde in Ägypten

An 2897 Laktationen einer Holstein-Friesian-Herde in Ägypten aus den Jahren 1987 bis 1993 wurden genetische Beziehungen zwischen Zwischentragezeit und Trockenstehzeit zum Milchertrag untersucht. Es konnte nachgewiesen werden, daß Kalbemonat und -jahr sowie Văter und Mutter innerhalb der Văter einen signifikanten Einfluß auf den Ertrag ausuben. Als signifikante lineare und quadratische Regressionskoeffizienten zwischen Milchertrag und Zwischentragezeit wurden 7,59 $\pm 0,40 \mathrm{bzw} .-0,37 \pm 0,00 \mathrm{~kg} / \mathrm{Tag}$ und für Trockenstehzeit $-9,37$ $\pm 0,54$ bzw. $0,02 \pm 0,00 \mathrm{~kg} / \mathrm{Tag}$ geschatzt. Hőhere Leistungen in der Folgelaktation sind demnach durch kürzere Zwischentrage- bzw. Trockenstehzeiten zu erwarten, so dass die Verkurzung beider Perioden ein wünschenswertes Ziel ist. Die geschătzten $\mathrm{h}^{2}$ Werte fulr die 305-Tage-Milchleistung, Zwischentragezeit und Trockenstehzeit betrugen $0,13 \pm 0,05,0,00$ und 0,00 . Die letzten beiden Merkmale ließen demnach keinen genetischen Einfluß auf den Milchertrag erkennen.

Schlusselworter: Zwischentragezeit, Trockenstehzeit, Milchertrag, genetische Beziehungen, Heritabilität 


\section{Introduction}

Days open (DO) from parturition to the subsequent conception affects milk yield and estimated breeding values (EBV) of cows and sires (BAR-ANAN and SOLLER, 1979; THOMPSON et al., 1982 and MAKUZA and MCDANIEL, 1996). With more days open, cows have more time to renew the body fat that is used for yield during the next lactation, and the converse may be expected. Relationships of these factors with milk yield are complex and are affected by management and environmental conditions (SCHAEFFER and HENDERSON, 1972; KHATTAB and ASHMAWY, 1988 and SADEK and FREEMAN, 1992).

Conception at $<100$ day postpartum (FUNK et al., 1987; LOUCA and LEGATES, 1968; SADEK and FREEMAN, 1992) and short dry period of $<40$ day (FUNK et al., 1987 and KHATTAB and ASHMAWY, 1988) depress milk yield during the subsequent lactation. High milk yield appears to be antagonistic to early conception because high yielding cows may not conceive as readily as low yielding cows (LABEN et al., 1982) and cow with more DO may have less interference from pregnancy on lactation milk yield. The usual management recommendation is a 60 day dry period (KHATTAB and ASHMAWY, 1988).

The range of $h^{2}$ estimate from the literature for various fertility traits (i.e., days open and calving interval) is from 0.00 to 0.12 (EVERETT et al., 1966; KHATTAB et al., 1987; ABDEL GLIL, 1996 and YENER et al., 1998b). Repeatability ranged from 0.00 to 67 (McDOWELL, 1972) which indicate that environmental influence are larger than genetic influences and this little change would be expected by selecting for fewer days open.

The objectives of this study are: (1) estimate phenotypic and genetic parameters for 305 day milk yield, days open and days dry, (2) estimation of sire breeding values for 305 day milk yield.

\section{Material and Methods}

They were 2897 lactation records made by Holstein Friesian cattle available for the present study. Animals are a part of the herd of Dena Farm far from Cairo City by 80 $\mathrm{km}$. Records were produced during the period 1987-1993 inclusive. Abnormal records affected by diseases or by disorders such as abortion were excluded. Also, records with lactation period shorter than 150 days were discarded. Total number of sires and daughters per sire were 234 and 12.16, respectively. All sires were used at random and artificial insemination were used. The genetic analysis included the sire which have at least 5 daughters.

Animals were allowed to graze during the period from December to May. During the rest of year, they were given concentrates and rice straw. Heifers were attempted for service for the first time when they reached 18 months or $350 \mathrm{~kg}$. Cows usually were served when seen in oestrus two months after calving. Rectal palpation for pregnancy diagnosis was performed 60 days after the last service. Cows in lactation were machine milked twice daily. Two months before the expected next calving date, the cows if already not dry were dried off. The length of days open was computed as the interval between the date of parturition and the date of successful mating or by subtracting the mean of gestation period, 275 days, from the actual calving interval if 
the date of successful mating was unknown. Traits studied are 305 day milk yield (305dMY), days open (DO) and dry period (DP).

\section{Analysis}

For the least squares analysis of variance, the following general linear model was used:

$$
Y=X \beta+Z \alpha+e
$$

where $Y$ was a vector of observations for each of the traits, $X$ was a known fixed design matrix, $\beta$ was an unknown vector of fixed effects representing the mean, year and month of calving and parity, $Z$ was a known design matrix, $\alpha$ was an unobservable random vector of effects of sire and cow within sire and $e$ was an unobservable random vector of errors with mean zero and variance - covariance matrix $I \sigma^{2} e$.

To study the effects of DO and DP on $305 \mathrm{dMY}$, the previous model was used including the effects of DO and DP as a polynomial regression of a second degree.

Estimates of sire, cow within sire and remainder components of variances and covariances were computed according to Methods II of HENDERSON (1953). Estimates of heritability $\left(\mathrm{h}^{2}\right)$ was calculated as four times the ratio of $\sigma^{2}{ }_{s}$ (sire variance components) and $\sigma_{\text {c:s }}^{2}$ (cow within sire variance components) over $\left(\sigma_{s}^{2}+\sigma_{c: s}^{2}+\sigma^{2}\right.$ e).

Approximate standard error of $\mathrm{h}^{2}$ was computed according to SWIGER et al. (1964). Estimates of genetic correlation (with standard errors) and phenotypic correlation were estimated as described in HARVEY (1987).

\section{Results and Discussion}

Means, standard deviations (SD) and coefficient of variability (CV\%) for different traits are presented in Table 1 . Mean of 305 day milk yield was $5006 \mathrm{~kg}$. The present mean was higher than those estimated by KHATTAB and ASHMAWY (1988), GHANEM et al. (1991), MANSOUR (1992), ABDEL GLIL (1996) and ÖNENC (1997) which ranged from 2388 to $4790 \mathrm{~kg}$. While, the present mean was lower than that estimated by KAYA (1996) (5334kg) working on Holstein Friesian cattle in Turkey. The mean of DO 124 was similar to estimate reported by MANSOUR (1992) (121d). While, lower than those reported by SALLAM et al. (1990) (158d). MAKUZA and McDANIEL (1996) using two herds of Holstein Friesian from Zimbabwe (herd1) and North Carolina (herd2). They found that DO ranged from 118 to $123 \mathrm{~d}$ for herd1 and from 118 to $132 \mathrm{~d}$ for herd2. Mean of DP was $100 \mathrm{~d}$. The present mean was higher than estimate reported by ABDEL BARY et al. (1992) (75d). An estimate of 111 and $84 d$ were reported by YENER et al. (1998a) using two herds of Holstein Friesian cattle. Pour management of Friesian cattle in Egypt lead to such high variation of CV's of DO and DP. The differences between the performance found here and those reported by other workers could be attributed to one or more of following reasons: (1) the herds were treated under different climatic and managerial conditions and or (2) different herds could possibly be genetically and phenotypically different from each other.

Results (Table 2) show that animals calving in spring months had the highest 305 day milk yield than those calving during the other seasons. These results agree with RAGAB et al. (1973), KHATTAB and ASHMAWY (1988), KHATTAB and SULTAN (1991), AFIFI et al. (1992), KAYA (1996) and YENER et al. (1998a). 
KHATTAB and ASHMAWY (1988) working on Friesian cattle in Egypt, found that milk yield in the different seasons are 2983,3157, 3030 and $3040 \mathrm{~kg}$ for winter, spring, summer and autumn calves, respectively. The high yield in spring calves could be attributed to the favourable climatic conditions for abundant growth and availability of good quality Egyptian clover (berseem) during the increasing stage of lactation.

Table 1

Means, standard deviations (SD) and coefficients of variability for different traits studied (Mittelwert, Standardabweichung und Variationskoeffizienten untersuchter Merkmale)

\begin{tabular}{lccc}
\hline Traits & Mean & SD & CV(\%) \\
\hline 305 dMY, kg & 5006 & 1325.9 & 26.49 \\
DO, d & 124 & 83.7 & 67.39 \\
DP,d & 100 & 64.7 & 64.76 \\
\hline
\end{tabular}

Year of calving had a significant effect of 305 day milk yield (Table 2). The present results are in close agreement with those founding by MOSTAGEER et al. (1986), SALLAM et al. (1990), AFIFI et al. (1992), KHATTAB et al. (1994), KAYA (1996) and YENER et al. (1998a). The effect of year of calving may be due to different nutritional, managerial practices and phenotypic trend.

Milk yield reached it's maximum in the third lactation and decreased somewhat there after. KHATTAB and ASHMAWY (1990) reported that the first lactation averaged $2728 \mathrm{~kg}$ and the mean increased to reach $2882 \mathrm{~kg}$ in the third lactation. This is logically due to the increase in body weight combined with advancing age and to the full development of the secretory tissue of the udder. Also, KAYA (1996) working on Holstein Friesian in Turkey arrived at the same results and found that the average 305 day milk yield were $4696 \mathrm{~kg}, 5352 \mathrm{~kg}, 5691 \mathrm{~kg}, 5739 \mathrm{~kg}$ and $5694 \mathrm{~kg}$ for $1^{\text {st }}, 2^{\text {nd }}$, $3^{\text {rd }}, 4^{\text {th }}$ and $5^{\text {th }}$ or greater lactation, respectively.

Least squares analysis of variance of 305 day milk yield is presented in Table 3 . Effects of month of calving, year of calving, parity, as a fixed effects, days open and days dry as a regression were significant $(\mathrm{P}<0.01)$.

Including DO as a polynomial regression of the second degree in the model yielded significant $(\mathrm{P}<0.01$, Table 3$)$, partial linear and quadratic regression coefficients of 305 day milk yield on DO, being $7.59 \pm 0.40 \mathrm{~kg} / \mathrm{mo}$ and $-0.37 \pm 0.00 \mathrm{~kg} / \mathrm{mo}^{2}$, respectively (Table 2). The curvilinear relationship of 305 day milk yield on DO is similar in trend to results reported by other workers from cattle (SCHAEFFER and HENDERSON, 1972; KHATTAB and ASHMAWY, 1988 ; SALLAM et al., 1990; ABDEL GLIL, 1996 and YENER et al., 1998a). FUNK et al. (1987) reported that lactation yield increased rapidly as current DO increased up to 100 days, the yield increased at a slower rate for longer period. Therefore from the economic standard point, reduction of DO is a desirable goal of dairymen.

Partial linear and quadratic regression coefficients of 305 day milk yield on dry period were significant, being $-9.37 \pm 0.54 \mathrm{~kg} / \mathrm{d}$ and $0.017 \pm 0.00 \mathrm{~kg} / \mathrm{d}^{2}$, respectively. DIAS and ALLARIE (1982) found that cows with calving interval less than 340 days required at least 95 days dry for increase milk production in two consecutive lactation. The present results agree with results obtained by KHATTAB and ASHMAWY (1988) and MAKUZA and McDANIEL (1996). The present results indicate that maximum production in the current lactation was attained when cows are breed as early as possible after parturition. 
Table 2

Least squares constants and standard error (SE) for factor affecting 305 day milk yield (305 dMY) (LeastSquares-Konstanten und Standardfehler der Einflußfaktoren auf die 305 Tage-Milchleistung)

\begin{tabular}{|c|c|c|c|}
\hline Classification & $\mathrm{N}$ & Const. & SE \\
\hline Month of calving & 2897 & 4860.2 & 53.87 \\
\hline 1 & 219 & 227.5 & 87.38 \\
\hline 2 & 182 & 252.7 & 86.25 \\
\hline 3 & 198 & 202.8 & 84.51 \\
\hline 4 & 156 & -160.2 & 85.60 \\
\hline 5 & 168 & -97.5 & 84.98 \\
\hline 6 & 203 & -150.3 & 78.43 \\
\hline 7 & 325 & -152.4 & 64.76 \\
\hline 8 & 383 & -192.6 & 59.84 \\
\hline 9 & 376 & -41.4 & 61.42 \\
\hline 10 & 239 & 13.4 & 74.14 \\
\hline 11 & 225 & 33.7 & 81.07 \\
\hline 12 & 223 & 64.4 & 83.18 \\
\hline \multicolumn{4}{|l|}{ Year of calving } \\
\hline 87 & 223 & -536.8 & 294.86 \\
\hline 88 & 498 & 189.7 & 190.39 \\
\hline 89 & 625 & 661.2 & 99.97 \\
\hline 90 & 731 & -10.6 & 50.96 \\
\hline 91 & 414 & 52.7 & 120.24 \\
\hline 92 & 249 & -29.1 & 196.90 \\
\hline 93 & 157 & -327.1 & 272.13 \\
\hline \multicolumn{4}{|l|}{ Parity } \\
\hline 1 & 802 & -344.6 & 255.19 \\
\hline 2 & 764 & 249.4 & 150.01 \\
\hline 3 & 567 & 360.8 & 66.07 \\
\hline 4 & 477 & 168.2 & 87.12 \\
\hline 5 & 232 & -110.9 & 164.55 \\
\hline 6 & 55 & -322.9 & 251.23 \\
\hline \multicolumn{4}{|l|}{ Regressions } \\
\hline DO, Linear & & 7.59 & 0.40 \\
\hline DO, Quadratic & & -0.37 & 0.00 \\
\hline DP, Linear & & -9.37 & 0.54 \\
\hline DP, Quadratic & & 0.017 & 0.00 \\
\hline
\end{tabular}

Table 3

Least squares analysis of variance for factors affecting 305 day milk yield ( $305 \mathrm{dMY}$ ) (Least-Squares-Analyse der Varianz von Einflußfaktoren auf die 305 Tage-Milchleistung)

\begin{tabular}{lcc}
\hline Source of variation & df & F value \\
\hline Sire & 233 & $1.07^{* *}$ \\
Cow :sire & 586 & $2.27^{* *}$ \\
Month of calving & 11 & $2.74^{* *}$ \\
Year of calving & 6 & $44.72^{* *}$ \\
Parity & 5 & $24.45^{* *}$ \\
Regressions & & \\
DO, Linear & 1 & $345.57^{* *}$ \\
DO, Quadratic & 1 & $69.51^{* *}$ \\
DP, Linear & 1 & $297.74^{* *}$ \\
DP, Quadratic & 1 & $97.04^{* *}$ \\
Remainder mean squares & 2051 & 819634.75 \\
\hline "*:(P<0.01) & &
\end{tabular}

Sire of the cow and cow within sires had highly significant effect on 305 day milk 
yield (Table 2). Cow evaluation and selection are important in herd improvement scheme. The ultimate aim of an evaluation is to enable breeders to compare their animals by the estimated producing ability. The present results are agree with results obtained by KHATTAB and SULTAN (1991) and SOLIMAN and EL-MENSHAWY (1994).

\section{Table 4}

Heritability estimates with standard errors (on diagonal), genetic correlation with standard errors (below diagonal) and phenotypic correlation (above diagonal) between different traits studied (Heritabilitătsschătzungen mit Standardfehler (auf der Diagonalen), genetische Korrelationen mit Standardfehler (unterhalb der Diagonalen), phănotypische Korrelationen (oberhalb der Diagonalen) zwischen den untersuchten verschiedenen Merkmalen)

\begin{tabular}{cccc}
\hline Traits & $305 \mathrm{dMY}$ & DO & DP \\
\hline $305 \mathrm{dMY}$ & $0.13 \pm 0.05$ & 0.24 & -0.16 \\
DO & 0.00 & 0.00 & 0.50 \\
DP & 0.00 & 0.00 & 0.00 \\
\hline
\end{tabular}

Estimates of $h^{2}$ for 305 day milk yield was $0.13 \pm 0.05$ (Table 4). Lower estimate of $h^{2}$ for milk yield were reported by WELLER et al. (1986), SALLAM et al. (1990), and ABDEL GLIL (1996) which ranged from 0.07 to 0.16 .

Heritability estimates for DO and DP were zero (Table 4). LOBO et al. (1962) found $\mathrm{h}^{2}$ estimates for DO derived from the sire components of variance were $0.01,0.05$ and 0.09 in first, second or later and all lactation, respectively. They also reported that the regression of daughter on dam for 449 daughter dam pairs were $0.02+0.00$. Also, low heritability estimates for DO were also reported by BERGER et al. (1981) (0.02 0.06), HANSEN et al. (1983) (0.02 - 0.03) and KHATTAB et al. (1987) (0.01). The low estimates of $\mathrm{h}^{2}$ indicate that a major part of variation in this character was environmental and selection would not be effective in bringing about genetic improvement. Better management can therefore play an important role in improving such that, in conclusion value of $\mathrm{h}^{2}$ for 305 day milk yield indicated that it can be improved milk yield though selection.

Phenotypic correlation between 305 day milk yield and each of DO and DP were 0.24 and -0.16 (Table 4). The present results indicated that milk yield increased as DO increased. Also it is increase as DP decreased. OLDS et al. (1979) estimated that each additional days open resulted in $4.5 \mathrm{~kg}$ more $305 \mathrm{dMY}$.

The simple correlation coefficients between two sets were positive and high (0.98) while simple correlation between the difference between (set1 - (set2 - set1)) were negative and not significant, (0.03). The present results suggested that adjustment of lactation records for days open would not involve genetic influence on yield and would not be valuable for either unbiased sire evaluation or cow evaluation.

\section{Acknowledgements}

I would like to thank Prof. Dr. A. S. KHATTAB for providing the data, his helpful discussion and his valuable comments.

\section{References}

ABDEL BARY, H.T.; MOHAMED, M.M.; ZAKY, H.I.; MOHAMED, A.:

Effects of season on month of calving on estrous performance, service per conception on milk yield of Friesian cows in Egypt. Egypt. J. Anim. Prod., 29 (1992), 229 
ABDEL GLIL, M. F.:

Estimation of genetic parameters and trend of some milk traits in a Herd of Friesian cows in Egypt. Egypt J. Anim. Prod. (in Press.), (1996)

AFIFI, A.E.; KHALIL, M.H.; EL-GLIL, M. F.; SULTAN, Z.A.:

Estimation of genetic parameters and sire values for milk production of Friesian cattle raised in Egypt. J. Anim. Prod., 29 (1992), 197

BAR-ANAN, R.; SOLLER, M.: The effect of days open on milk yield and on breeding policy postpartum. J. Anim. Prod., 29 (1979),
109

BERGER, P.J.; SHANKS, R.D.; FREEMAN, A.E.; LABEN, R.C.:

Genetic aspects of milk yield and reproductive performance in Jersey Cattle. J. Dairy Sci., 64 (1981), 114

DIAS, F.M.; ALLAIRE, F.R.:

Dry period to maximize milk production over two consecutive lactation. J. Dairy Sci., 65 (1982), 136

EL-CHAIFE, O.M:

Studies in cattle (cows and buffaloes) sire evaluation and genetic parameters of partial lactation's day period and service period. M. Sc. Thesis, Faculty of Agriculture Alex. Univ. Egypt, (1981)

EVERETT, R.W.; ARMSTRONG, D.V.; BOYD, L.J.: Genetic relationship betweeen production and feeding efficiency. J. Dairy Sci., 49 (1966), 879

FUNK, D.A.; FREEMAN, A.E.; BERGER, D.J.:

Effect of previous days open, previous days dry and present days open on lactation yield. J. Dairy Sci., 70 (1987), 2366

GHANEM, Y.S.; MANDOUR, M.; EL-BAYOMI, K.M.; BADRAN, A.E.: Genetic parameters of some lactations traits in Friesian cows in Egypt. Zagazis. J. Agric. Res., 8 (1991) 1, 1071

HANSEN, L.B.; FREEMAN, A.E.; BERGER, P.J.: Yield and fertility relationships in dairy cattle. J. Dairy Sci., 66 (1983), 293

HENDERSON, C.R.:

Estimation of variance and covariance components. Biometrics, 9 (1953), 226

HARVEY, W.Y.:

Mixed Model Least Squares and Maximum Likelihood Computer Program. PCI. Ohio State Univ., KAYA, I.: Columbus, M.S.A. (Mimeograph), (1987)

Parameter estimates for persistency of lactation and relationship of persistency with milk yield in Holstein cattle. Ph. D. Thesis. Ege Univ. Izmir, Turkey, (1996)

KHATTAB, A.S.; ASHMAWY, A.A.,:

Relationships of days open and day period with milk production in Friesian cattle in Egypt. J. Anim. Beed. Genet., 105 (1988), 300

KHATTAB, A.S.; ASHMAWY, A.A.,: Factors for Standardizing 305 Day Lactation Records of Friesian Cows for Age at Calving. Egypt J. Anim. Prod., 27 (1990), 161

KHATTAB, A.S.; SULTAN Z.A.: A comparison of different selection indices for genetic improvement of some dairy traits in Friesian cows in Egpyt. J. Anim. Breed. Genet., 108 (1991), 439

KHATTAB, A.S.; MABROUK, M.M.S.; EL-HAKIM, A.M.: Lactation records adjusted for days open in sire evaluation. J. Agri. Res. Tanta Univ., 13 (1987), 286

KHATTAB, A.S.; ABDEL GLIL, M.F.; SALEM, A.Y.:

Estimation of genetic parameters and sire values for lifetime production and longevity traits in Friesian cows in Egypt. J. Agric. Sci., Mansoura Univ., 19 (1994), 483

LABEN, R.L.; SHANKES, R.; BERGEN, P. J.; FREEMAN, A.E.: Factors effecting milk yield and reproductive performance. J. Dairy Sci., 65 (1982), 1004

LOBO, R.B.; DUARTE, F.A.M.; GONCALES, A.A.M.; OLIVERIA, J.A.; WILCOX, C.J.: Genetic and environmental effects on milk yields of Pitangueiras cattle. Anim. Prod., 39 (1962), 157

LOUCA, A.; LEGATES, J.E.: Production losses in dairy cattle due to days open. J. Dairy Sci., 51 (1968), 573

MAKUZA, S.M.; McDANIEL, T.C.:

Effects of days dry, previous days open and current days open on milk yield of cows in Zimbabwe and North Carolina. J. Dairy Sci., 79 (1996), 702 
MANSOUR, H.:

Some reproductive performance parameters of Holstein cattle in the Kingdom of Saudi Arabia. Annals Agri. Sci., (1992), 37

McDOWELL, R.E.: Improvement of livestock production in warm climatices. W.H. Freeman and Co San Francisco. CA., (1972)

MOSTAGEER, A.; AFIFI, Y.A.; MORSEY, M.A.; NIGM, A.A.:

Grading up Baladi cattle with Friesian in Egypt. J. Anim. Breed. Genet., 104 (1986), 383

OLDS, D.T.; COOPER, T.; THRIFT, F.A.:

Relationships between milk yield and fertility in dairy cattle. J. Dairy Sci., 62 (1979), 1140

ONENEC, A.:

A technical analysis of dairy cattle productive activities at Menemen Research, Practice and Production Farm of Ege Univ. M. Sc. Thesis., Izmir, Turkey, (1997)

RAGAB, M.T.; ABDEL AZIZ, A.S.; MOURAD, H.M.:

Phenotypic and genetic parameters of some productive traits in a herd of Friesian cows in Egypt. Egypt. J. Anim. Prod., 13 (1973), 1

SADEK, M.H.; FREEMAN, A.E.:

Adjustment factors for previous and present days open considering all lactation. J. Dairy Sci., 72 (1992), 279

SALLAM, M.T.; EL-FEEL, F.M.R.; KHATTAB, A.S.:

Effect of genetic and nongenetic factors on productive and reproductive traits in Friesian cows in Egypt. Minia. J. Agric. Res. and Dev., 12 (1990), 521

SCHAEFFER, L.R.; HENDERSON, J.R.:

Effects of days dry and days open on Holstein milk production. J. Dairy Sci., 55 (1972), 107

SOLIMAN, A.M.; MARAI EL-MENSHAWY, S.M.:

Age at calving, days open and lactation length correction factors for total milk yield and repeatability estimate of some productive and reproductive traits in Egyptian Buffaloes raised in under desert conditions. Annals of Agric. Sci., Moshtoher, Egypt, (1994)

SWIGER, L.A.; HARVEY, W.R.; EVERSON, D.O.; GREGORY, K.E.:

The variance of intraclass correlation involving groups. Biometrics, 20 (1964), 818

THOMPSON, J.R.; FREEMAN, A.E.; BERGER, P.J.:

Days open adjusted, annualized and fat corrected yield as alternatives to mature equivalent records. J. Dairy Sci., 65 (1982), 1562

WELLER, J.I.; RAN, M.; BAR ANAN, S.:

Multiplication genetic analysis of Israeli dairy cattle population. $3^{\text {td }}$ World Congress on Genetic. Applied to Livestock Prod., USA, (1986)

YENER, S.M.; AKMAN, N.; KHATTAB, A.S.:

Analysis of milk traits in two herds of Holstein Friesian cattle in Turkey and Egypt. I - Non genetic factors. Turkish J. Vet. and Anim. Sci. (in Press.), (1998a).

YENER, S.M.; AKMAN, N.; KHATTAB, A.S.:

Analysis of milk traits in two herds of Holstein Friesian cattle in Turkey and Egypy. II - Phenotypic and genetic parameters. Turkish J. Vet. and Anim. Sci. (in Press.), (1998b).

Received: 1998-10-23

Accepted: 2000-10-10

Author's address

Prof. Dr. HÜLYA ATIL

Faculty of Agriculture, Ege University

Izmir

Turkey 